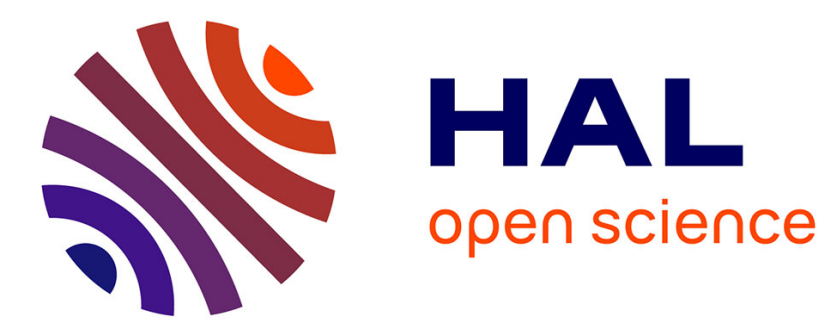

\title{
Determination by echography of uterine changes around puberty in gilts and evaluationof a diagnosis of puberty
}

Françoise Martinat-Botté, Eric Royer, Eric Venturi, Christian Boisseau, Philippe Guillouet, Vincent Furstoss, Michel Terqui

\section{- To cite this version:}

Françoise Martinat-Botté, Eric Royer, Eric Venturi, Christian Boisseau, Philippe Guillouet, et al.. Determination by echography of uterine changes around puberty in gilts and evaluationof a diagnosis of puberty. Reproduction Nutrition Development, 2003, 43 (3), pp.225-236. 10.1051/rnd:2003022 . hal-00900450

\section{HAL Id: hal-00900450 \\ https://hal.science/hal-00900450}

Submitted on 1 Jan 2003

HAL is a multi-disciplinary open access archive for the deposit and dissemination of scientific research documents, whether they are published or not. The documents may come from teaching and research institutions in France or abroad, or from public or private research centers.
L'archive ouverte pluridisciplinaire HAL, est destinée au dépôt et à la diffusion de documents scientifiques de niveau recherche, publiés ou non, émanant des établissements d'enseignement et de recherche français ou étrangers, des laboratoires publics ou privés. 


\title{
Original article
}

\section{Determination by echography of uterine changes around puberty in gilts and evaluation of a diagnosis of puberty}

\author{
Françoise MARTINAT-BOTTÉa* ${ }^{a}$ Eric ROYER ${ }^{\mathrm{a}}$, Eric VENTURI ${ }^{\mathrm{a}}$, \\ Christian BOISSEAU ${ }^{\mathrm{b}}$, Philippe GUILLOUET ${ }^{\mathrm{b}}$, Vincent FURSTOSS ${ }^{\mathrm{b}}$, \\ Michel TERQUI ${ }^{\mathrm{a}}$
}

${ }^{a}$ UMR 6073 INRA-CNRS-Université F. Rabelais PRC, 37380 Nouzilly, France
${ }^{b}$ UEICP INRA, 86480 Rouillé, France

(Received 2 December 2002; accepted 4 April 2003)

\begin{abstract}
Three experiments were carried out to evaluate the use of ultrasonography in assessing the onset of puberty in gilts. In experiment 1 , gilts $(n=17)$ were scanned 3 times per week beginning at 133 and continuing until 187 days of age. The ultrasonic appearance of the uterus was described, quantified and compared with the reproductive status observed at slaughter. The quantification of the pictures showed a different correlation in time for infantile, impubertal, prepubertal and pubertal stages. For pubertal females, "uterine area" increased at around 180 days of age, well-defined sections of the uterine horns appeared $3 \pm 0.5$ days before puberty. In infantile and impubertal gilts during the same period of age, uterine images remained dark and homogeneous; no significant change in the "uterine area" was observed. This difference in images allowed an evaluation of the diagnosis of puberty. In experiment 2 , the gilts $(n=123)$ were scanned, the result was verified at slaughter the day after by examination of the genital tract. The uterine weight of the gilts that had reached a prepubertal or pubertal stage was significantly greater $(P=0.0001)$ than that in impubertal gilts. The sensitivity and the specificity of the diagnosis were $91.9 \%$ and $96.5 \%$ respectively. Experiment 3 was performed on a farm and echographic examinations were carried out one and five days after gilts $(n=117)$ arrived at the piggery. Oestrus detection or blood sampling for progesterone determinations were used as tools to determine the reproductive status. The sensitivity and the specificity of the diagnosis were $98.9 \%$ and $100 \%$ respectively. This diagnosis of puberty is thus accurate.
\end{abstract}

pig / puberty / detection / ultrasonography

* Corresponding author: fbotte@tours.inra.fr 


\section{INTRODUCTION}

In gilts, early puberty is considered necessary for the best economic management of females [1-5]. In a group of gilts, the spontaneous occurrence of the first oestrus is generally spread over several weeks; within the Large White breed, a range around 15 weeks has been recorded between the earliest and the oldest age [6]. Environmental and management conditions influence the timing of puberty [7]. The presence of the boar accelerates the occurrence of puberty [8] and when associated with transport stress, allows synchronisation of an increased proportion of first oestrus within a few days. However, the results of such procedures are highly variable $[9,10]$.

During sexual development different periods have been described for the Large White and the last one corresponds to 5-6 months of age which is near puberty. This period has been characterised by a decrease in LH and FSH secretions and an increase in ovarian secretions [11] which act on uterine development and the central nervous system $[2,7,12$, 13]. The growth of the uterus has been observed during this period $[14,15]$.

The purpose of this study was to find another method than the detection of oestrus by a boar to estimate the onset of puberty in gilts. Ultrasonography was selected because this method is able to visualise uterine evolution during early pregnancy and post-partum [16]. First, the changes in the uterus were monitored by ultrasonography prior to and around the time of puberty. Second, the ultrasonographic images were related to the physiological status: infantile, impubertal, prepubertal or pubertal. Third, a diagnosis of puberty based on the difference of uterine images has been evaluated in practical conditions.

\section{MATERIALS AND METHODS}

Three experiments were conducted from July 1999 to June 2001.

\subsection{Experiment 1: \\ Determination of uterine changes at the echographic examination and slaughter}

Large White hyperprolific gilts $(n=17)$ came from the INRA pig herd in Nouzilly (France). Females received a commercial diet in collective troughs $\left(2.2 \mathrm{~kg} \cdot \mathrm{day}^{-1}\right)$ and were accommodated in-groups of 4 to 6 in pens with natural daylight.

Oestrus was detected once per day from 133 days of age onward (the first day of echographic follow-up). The gilts were moved from their pens and placed in direct contact with an adult boar for at least 5 minutes. The gilts were recorded in oestrus when a female demonstrated all behaviour characteristics ("standing" reaction, active pursuit of the male, etc.) described by Signoret [17] and Terqui et al. [18].

The gilts were examined by echography 3 times a week (Monday, Wednesday, and Friday) from 133 to 187 days of age. The gilts were immobilised into a crate adapted to the size of the gilts. To prevent the gilts from moving during the examination, some feed was distributed. This procedure frequently allowed better visualisation of the uterus. The ultrasound equipment used was an Aloka SSD 650. The examination procedure described for adult sows [16] was modified for 6-month-old gilts. For these gilts, the examination was carried out externally on the right side of the gilt by applying the linear probe $(5 \mathrm{MHz})$ only in the inguinal fold. The transmitting zone of the transducer was coated with contact gel. The probe was placed as high as possible in the inguinal zone and firmly pressed on the animal's skin to visualise the uterus.

For each ultrasound examination, the images were recorded on a S-VHS videotape and analysed subsequently. The qualitative aspect of echographic images were noted. At each uterine visualisation, from one to five scans were fixed. For each scan, the height occupied by the uterus in the image 
or the "uterine height" (in $\mathrm{cm}$ ) was measured at different places. The area occupied by the uterus in the image or "uterine area" (in $\mathrm{cm}^{2}$ ) was also measured. All these measurements were computed by the way of the software integrated in Aloka SSD 650 equipment. Figure 1 indicates how the "uterine height" and the "uterine area" were defined.

The means $( \pm$ SD) of age and weight of the gilts at slaughter were $184 \pm 2$ days and $112 \pm 13 \mathrm{~kg}$ respectively. Each genital tract was collected and observed. The physiological status was noted as described by Martinat-Botté et al. [16]: (1) infantile were those gilts whose uterus was still small and whose ovaries presented smaller follicles $(<0.5 \mathrm{~cm})$ and no other structures, (2) impubertal were those gilts whose uterus began to grow and vascularise and whose ovaries presented no other structures than follicles (between 0.1 and $0.6 \mathrm{~cm}$ ), (3) prepubertal gilts which had uteri which were developed and had a few follicles between 0.6 and $0.8 \mathrm{~cm}$ on the ovaries, and (4) pubertal gilts which had a developed uterus and ovaries with corpora lutea and/or corpora albicantia, and follicles. After dissecting the broad ligament, the uterus was weighed (in g).

\subsection{Experiment 2: Evaluation of a diagnosis of puberty}

This experiment was performed on Large White hyperprolific gilts $(n=123)$ coming from the INRA pig herd in Nouzilly (France). Thus, the management was identical with that of experiment 1 . The detection of the first oestrus was done with a boar once per day from 150 days of age onward.

Large White hyperprolific gilts of $206 \pm$ 8 days of age and weighing $123 \pm 11 \mathrm{~kg}$ were examined by echography only once with the same procedure as that described previously (see experiment 1 ).
For the diagnosis, the echographic images of the uterus were codified. Females were noted + when well defined slices of the uterus were visualised. Females were recorded - when the uterine images were dark and homogeneous.

One day after the ultrasound scanning, the gilts were slaughtered; the genital tract of each gilt was observed and the uteri of only 73 gilts were weighed. For each gilt, the physiological status was noted as described above (experiment 1) and compared to the result of the ultrasound examination. Then, the accuracy of the diagnosis was calculated (see Sect. 2.4).

\subsection{Experiment 3: Example of practical use of puberty diagnosis}

Crossbred gilts $(n=117)$ from a commercial hybrid strain and originating from the same herd were introduced into an INRA piggery in Rouillé (France). The gilts were accommodated in groups of 4 to 6 in pens (natural daylight) and received a commercial diet in collective troughs $\left(1.4 \mathrm{~kg} \cdot \mathrm{day}^{-1}\right)$.

The mean age was $202 \pm 8$ days and the average weight $114 \pm 11 \mathrm{~kg}$ when the gilts were transported by road in groups of $12 \mathrm{ev}-$ ery three weeks, to the experimental building. On arrival, the gilts were penned in lots of four and housed near to an adult boar. Oestrus detection was performed twice daily from the time of their arrival. Those gilts not observed in oestrus were blood sampled at 5 and 12 days after transportation and thereafter at 14-day intervals. These samples were used for progesterone radioimmunoassay to determine the physiological state of the female: pubertal with a high level of progesterone $\left(>2 \mathrm{ng} \cdot \mathrm{mL}^{-1}\right)$ or not pubertal with a low level of progesterone $\left(<2 \mathrm{ng} \cdot \mathrm{mL}^{-1}\right)$ in two successive samples [10].

$\mathrm{D}_{0}$ was the day of gilt arrival and the echographic examinations were carried out on Days 1 and 5 for all purchased gilts. The 
Photo l:

Infantilc gilt - the utcrus was restrained between the bladder and the intestinal mass. Images of the uterus were homogeneous.
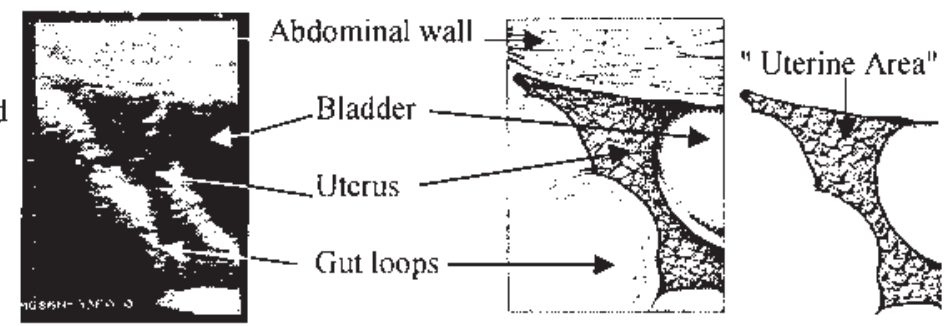

Photo 2:

Impubertal gilt the uterus encircled the bladder. Uterine images were more and less dark and homogeneous.
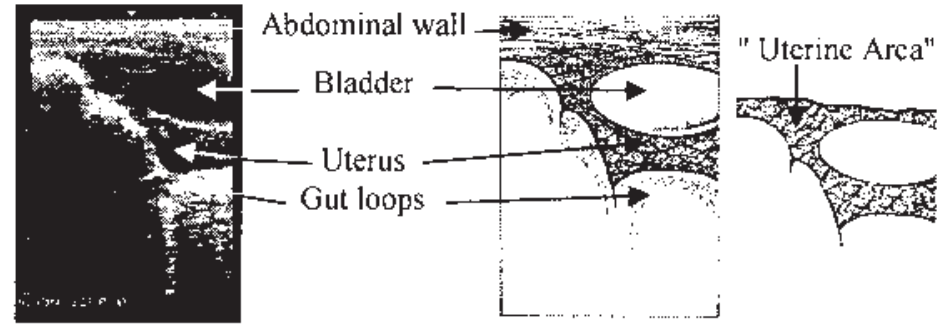

Photo 3:

Sections of the uterus of a prepubertal gilt. Uterine sections were easy to distinguish, the images were contrasted.
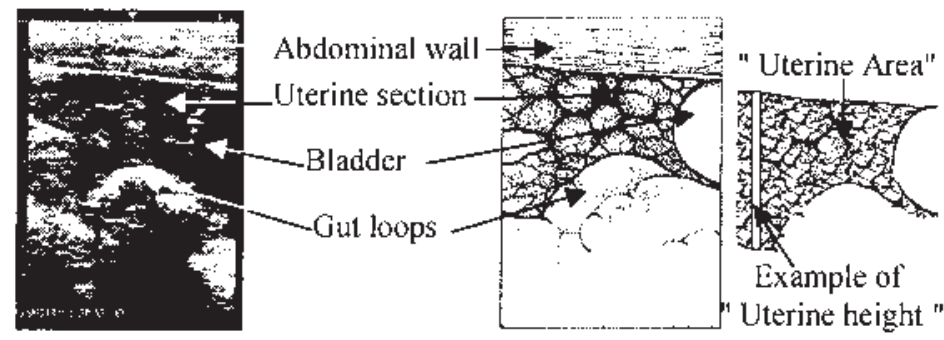

Photo 4: Uterine sections of a gilt two days after the puberty. Sections of uterine horns were visible.

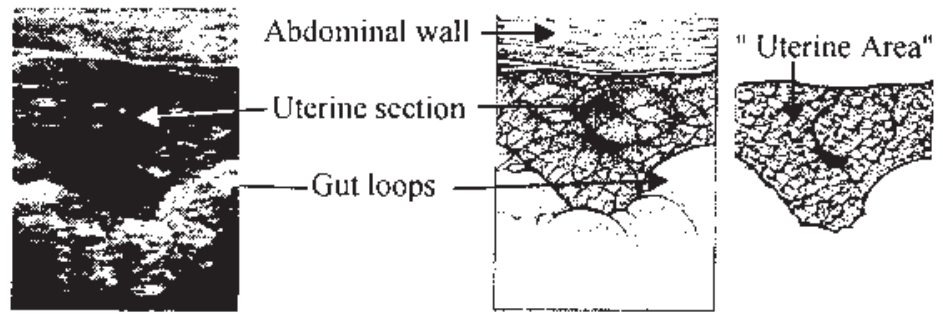

Figure 1. Ultrasound images of the uterus in females with different physiological status. Drawings were done by Guy Renaud (UEICP INRA 86480 Rouillé, France). 
follow-up was continued at around 7-day intervals for the gilts not observed in oestrus during the week after transport. The ultrasound equipment used was an Aloka SSD 500. The examination procedure was the same as that described for experiments 1 and 2.

The echographic images of the uterus were codified as explained for experiment 2 and were compared to the physiological status of the gilt.

For this experiment, the physiological status of the gilts was classified as follows:

(1) infantile or impubertal gilts were those which did not express oestrus and with a low level of progesterone in at least two successive samples, (2) pubertal gilts which were observed either in oestrus or with a high level of progesterone detected without oestrus being observed [10].

\subsection{Calculation mode of diagnosis accuracy}

The results of the ultrasound examinations were compared to the physiological status of the gilts for the experiments 2 and 3. There were four cases:

True positive (TP: ++ ): the examination result was + and corresponded at slaughter to prepubertal and pubertal gilts (experiment 2) or to gilts seen in oestrus or with a high level of progesterone detected (experiment 3 ) and noted + .

False positive (FP: +-$)$ : the examination result was + and corresponded at slaughter to infantile and impubertal gilts (experiment 2) or to gilts which did not come in oestrus and with a low level of progesterone in at least two successive samples (experiment 3) and noted -. In this case, we have considered that there was a false positive diagnosis.

True negative (TN: --$)$ : the examination result was - and corresponded at slaughter to infantile and impubertal gilts (experiment 2) or to gilts which did not come in oestrus and with a low level of progesterone in at least two successive samples (experiment 3) and coded -.

False negative $(\mathrm{FN}:-+)$ : the examination result was negative and corresponded at slaughter to prepubertal and pubertal gilts (experiment 2) or to gilts seen in oestrus or with a high level of progesterone detected (experiment 3 ) and noted + . In this case, we considered that there was a false negative diagnosis.

The sensitivity of the diagnosis was defined as the number of true positives (TP) as a proportion of all results from truly prepubertal and pubertal gilts $(\mathrm{TP}+\mathrm{FN})$ and given as percentage. The specificity of the test was defined as the number of correct negatives (TN) as a proportion of the total test results for truly infantile and impubertal gilts $(\mathrm{TN}+\mathrm{FP})$ and expressed in percentage. The accuracy of diagnosis was calculated as the ratio between correct diagnoses and the number of diagnoses carried out, given in percentage.

\subsection{Statistical analyses}

They were performed using S-Plus [19] and SAS software [20].

The effect of the physiological status on the age and weight of the uterus was tested with ANOVA.

The comparison of the evolution of the uterine area between pubertal, infantile and impubertal gilts was performed as suggested by Littel et al. [21] for repeated measurements. The prepubertal status was not included in the analysis since only one gilt was in this status. Thus 16 gilts were involved. The period of comparison was restricted to 137 to 183 days of age and the observations of two consecutive days were grouped in order to have no empty cells. The MIXED procedure of SAS was selected because it allows missing observations for one animal and modeling the variance and correlation structure (CS) of the repeated 
measures. The model included in the MIXED procedure with options was:

Uterine area $=$ status time status $*$ time;

Repeated time $/$ subject $=$ gilt (status) type $=$ CS.

The occurrence of changes of the uterine horns was characterised with event history analysis.

The accuracies of ultrasound diagnoses were compared to slaughter results (experiment 2) or the appearance of oestrus or not (experiment 3 ) with the Kendall coefficient of concordance.

\section{RESULTS}

\subsection{Experiment 1: Determination of uterine changes at the echographic examination and slaughter}

The age at puberty was observed at $178 \pm$ 5 days $(\mathrm{X} \pm \mathrm{SD})$. Puberty was noted in 10 of the slaughtered gilts (59\%) and an ovulation was observed in 3 of them without oestrus behaviour.

\subsubsection{Changes in ultrasound images around puberty (Fig. 1)}

For each gilt, 23 to 25 examinations were done during the experimental period.

For infantile and impubertal gilts at slaughter, uterine images remained more and less dark and always homogeneous during the whole period (Photos 1 and 2). The uterus took up much less place than the gut loops and bladder (Photos 1 and 2). The uterus was often restrained between the bladder and the intestinal mass (Photo 1). In such situations, the probe has to be moved. Sometimes, the uterus was behind the bladder. The ovaries were never seen for the infantile and impubertal gilts.

For pubertal gilts at slaughter, until 165 to 170 days old, the uterine images remained more and less dark and homogeneous.
The same difficulties described above for immature gilts were encountered during this period. The ultrasonographic images of the uterus changed a few days before the onset of puberty. Well defined sections of the uterine horns were observed on the screen (Photos 3 and 4). Uterine sections were visualised under or near the bladder.

This type of echographic images sometimes occured 9 days (maximum) before puberty but in the majority of the cases, it was observed five to one day before puberty, as illustrated in Figure 2. The mean time was 3.3 days \pm 0.49 (mean \pm se) before puberty; this kind of image was always visualised. In three gilts which had ovulated without showing oestrus, changes of the images of the uterus were also observed. One gilt was prepubertal at slaughter, the uterine sections were observed four days before. The ovaries with follicles were seen the day before slaughter (not shown on Photo 3). Those had permitted to know the real physiological state of this gilt and it was very close to puberty.

\subsubsection{Changes of uterine weight}

The mean uterine weight varied significantly according to physiological status. For the pubertal gilts, the uterine weight ( $359 \mathrm{~g}$ ) was around 8 times heavier than that of the infantile gilts (48 g, $P=0.007$, Tab. I).

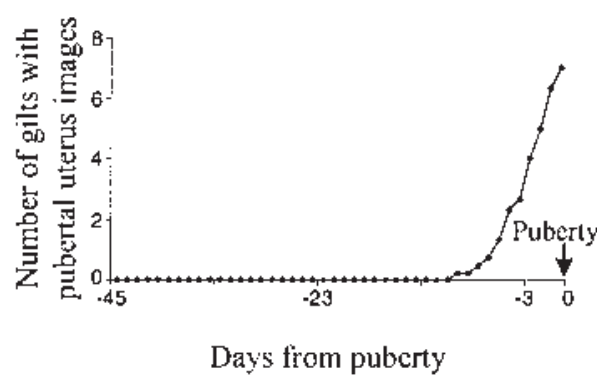

Figure 2. Occurrence of ultrasound pubertal images of the uterus around puberty $($ day $=0)$ for gilts with oestrus ( $n=7$; experiment 1$)$. 
Table I. Age (days) and uterine weight ( $\mathrm{g}$ ) and "uterine area" $\left(\mathrm{cm}^{2}\right)$ of gilts at slaughter according to physiological status (experiments 1 and $2 ; \mathrm{X} \pm \mathrm{SD}$ ).

\begin{tabular}{|c|c|c|c|c|c|c|c|}
\hline \multirow[b]{2}{*}{$\begin{array}{c}\text { Physiological } \\
\text { status }\end{array}$} & \multicolumn{4}{|c|}{ Experiment 1} & \multicolumn{3}{|c|}{ Experiment 2} \\
\hline & $\begin{array}{c}\text { Number } \\
\text { of gilts }\end{array}$ & $\begin{array}{l}\text { Age at } \\
\text { slaughter } \\
\text { (days) }\end{array}$ & $\begin{array}{l}\text { Uterine } \\
\text { weight } \\
\text { (g) }\end{array}$ & $\begin{array}{c}\text { Mean } \\
\text { uterine } \\
\text { area }\left(\mathrm{cm}^{2}\right)^{*}\end{array}$ & $\begin{array}{l}\text { Number } \\
\text { of gilts }\end{array}$ & $\begin{array}{l}\text { Age at } \\
\text { slaughter } \\
\text { (days) }\end{array}$ & $\begin{array}{l}\text { Uterine } \\
\text { weight } \\
\text { (g) }\end{array}$ \\
\hline Infantile & 2 & $181-182$ & $46-50$ & $3.5 \pm 2.3^{\mathrm{h}}$ & 0 & - & - \\
\hline Impubertal & 4 & $182 \pm 13^{\mathrm{a}}$ & $120 \pm 11^{\mathrm{b}}$ & $13 \pm 5.6^{\mathrm{i}}$ & 55 & $201 \pm 7^{\mathrm{a}}$ & $118 \pm 59^{\circ}$ \\
\hline Prepubertal & 1 & 184 & 291 & 30.2 & 9 & $201 \pm 7^{\mathrm{a}}$ & $258 \pm 75^{t}$ \\
\hline Pubertal & 10 & $185 \pm 14^{\mathrm{a}}$ & $359 \pm 18^{\mathrm{c}}$ & $40.5 \pm 7.2^{\mathrm{j}}$ & 9 & $210 \pm 8^{\mathrm{d}}$ & $534 \pm 95^{\circ}$ \\
\hline
\end{tabular}

* The day before slaughter.

Means of the same row with different superscipts are different: ${ }^{\text {bc }} P=0.007$; ad $P=0.007$;

${ }^{\text {efg }} P=0.0001 ;{ }^{\text {hij }} P=0.0002$.

\subsubsection{Relation between uterine weight and "uterine area"}

For this analysis, we only took account of "uterine height" and "uterine area" measured one day before slaughter. The correlation between the weight of the uterus and "uterine area" was slightly better $(r=0.92$; $P<0.00001)$ than that calculated between the weight of the uterus and "uterine height" $(r=0.88, P<0.0002)$. For this reason, the "uterine area" parameter was taken as the reference for subsequent analysis.

\subsubsection{Changes of "uterine area" around puberty}

Figure 3 shows the changes of "uterine area" during the echographic follow-up (54 days on average) for 10 pubertal gilts (with or without oestrus) and for those which were infantile, impubertal and prepubertal (7 gilts) at slaughter.

For the pubertal females whose oestrus was detected, the "uterine area" increased rapidly around 180 days old which was near puberty (Fig. 3d).

Three gilts not seen in oestrus were pubertal at slaughter. For these females, an increase in "uterine area" was observed around 180 days of age (Fig. 3e). The same trend was noted for the only one prepubertal gilt at slaughter (Fig. 3c).

Conversely, "uterine area" values remained low during the echographic followup for infantile and impubertal females at slaughter (Figs. 3a and 3b).

The changes of "uterine area" was compared between pubertal $(n=10)$ and infantile plus impubertal $(n=6)$. The results of the statistical analysis showed that this evolution (status*time) was significantly different between these two groups $(\mathrm{F}=6.47$; $\mathrm{df}=$ $1.22 ; P=0.0001)$. As described above, the evolution differed significantly $(P<0.001)$ on the last days between 179 and 182 days of age.

\subsection{Experiment 2: Evaluation of a diagnosis of puberty}

$70 \%$ of slaughtered gilts $(n=86)$ were infantile and impubertal gilts. Only $11 \%$ of them were observed in oestrus before slaughter and therefore their ages at puberty were not determined. Among the pubertal females $(n=24), 8 \%$ had ovulated without oestrus. Similar significant differences 
a

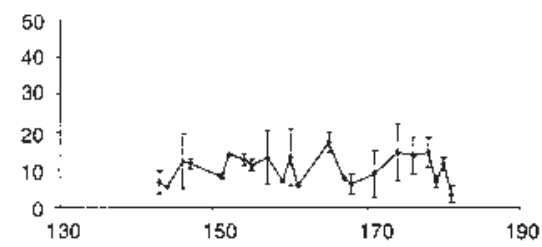

b
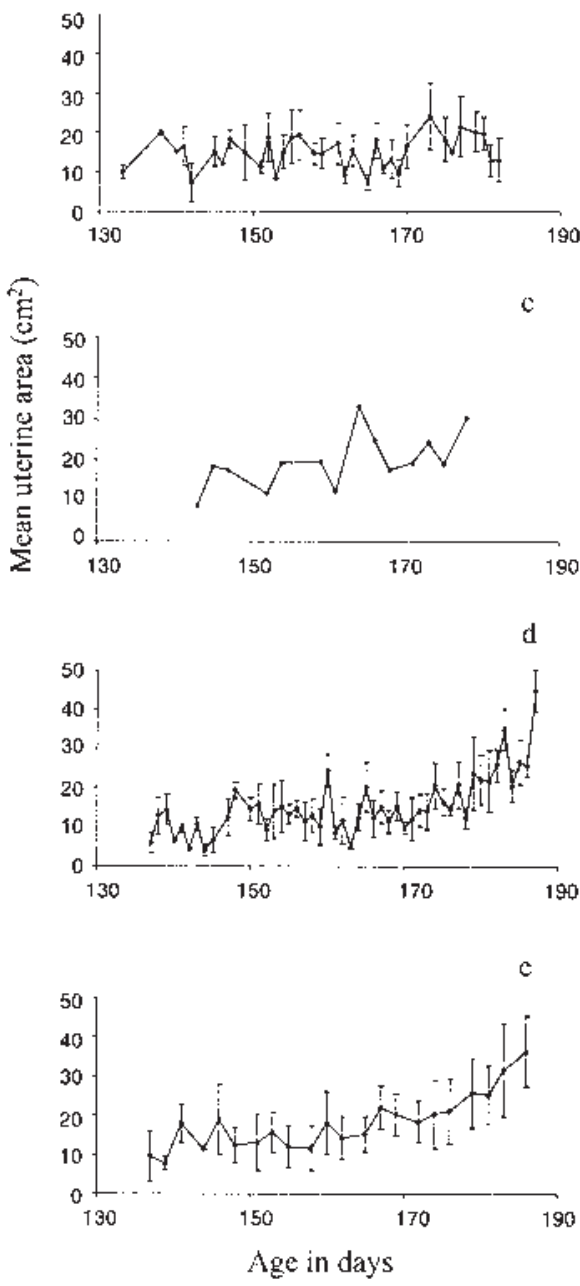

Figure 3. Evolution of "uterine area" in hyperprolific Large White gilts between 130 and 190 days old (experiment $1 ; \mathrm{X} \pm \mathrm{SD}$ - except for c). (a) Infantile gilts at slaughter $(n=2)$, (b) Impubertal gilts at slaughter $(n=4)$, (c) Prepubertal gilt at slaughter $(n=1)$, (d) Pubertal gilts seen in oestrus before slaughter $(n=7)$, (e) Pubertal gilts not seen in oestrus before slaughter $(n=3)$. 
Table II. Diagnosis accuracy of puberty in gilts.

\begin{tabular}{cccc}
\hline Experiment & Number of gilts & Diagnosis of puberty & $(\%)$ \\
\hline \multirow{2}{*}{2} & 37 & Sensitivity & 91.9 \\
& 86 & Specificity & 96.5 \\
& 123 & Accuracy & 95.1 \\
\hline \multirow{2}{*}{$3^{\text {a }}$} & 95 & Sensitivity & 98.9 \\
& 22 & Specificity & 100 \\
& 117 & Accuracy & 99.1 \\
\hline
\end{tabular}

${ }^{\text {a }}$ Calculated for the second ultrasound examination.

between uterine weight were noted as in experiment 1: pubertal females had heavier uteri as compared to impubertal gilts $(P=$ 0.0001; Tab. I).

The overall diagnosis accuracy was $95.1 \%$ (Tab. II) but this parameter varied according to the physiological status. No error of diagnosis was noted on the pubertal gilts with $(n=14)$ or without $(n=10)$ oestrus being detected. Three errors of diagnosis on prepubertal gilts $(n=13)$ were noted. For reasons described above (see Sect. 3.1.1), prepubertal females were included with pubertal gilts to calculate diagnosis accuracy. Three diagnosis errors on impubertal gilts were observed. The sensitivity and the specificity of the test were $91.9 \%$ and $96.5 \%$ respectively (Tab. II).

The echographic diagnosis was concordant to the physiological status observed at slaughter since no significant difference $(P=0.15)$ was observed between the two types of observations.

\subsection{Experiment 3: \\ Example of practical use of a diagnosis of puberty}

The age at puberty occurred at $210 \pm$ 14 days $(\mathrm{X} \pm \mathrm{SD})$. A high proportion of gilts $(n=93)$ were in oestrus within 8 days after arrival at the piggery and $96 \%$ within one month after the arrival at the piggery and $2 \%$ had ovulated without oestrus behavior.
For the first echography $\left(\mathrm{D}_{1}\right)$, most of the examinations $(n=78)$ issued diagnosis + . The second echography at $\mathrm{D}_{5}$ confirmed that these gilts were + (Fig. 4a).

Two gilts presented a silent ovulation as detected by progesterone assay and diagnosed + at their second echography. Thus no error was made. For 20 gilts $(17 \%)$ at $D_{1}$ and $\mathrm{D}_{5}$ all echographic examinations resulted in a negative diagnosis. Figure $4 b$ shows the occurrence of the onset of oestrus of this group of females, most of them demonstrated a delayed oestrus ( $>11$ days after arrival). In this group, a false negative diagnosis (FN: -+ ) was made for the gilt whose onset of oestrus occurred 5 days after arrival at the piggery (Fig. 4b). The follow-up by echography was continued at around 7-day intervals. The difference of the images was observed always for gilts that became pubertal. Two gilts were diagnosed - at each echography (4 and 10 examinations done respectively) that was confirmed at slaughter: both gilts were impubertal.

If we only take the second examination (at $\mathrm{D}_{5}$ ) into account, overall diagnosis accuracy was $99.1 \%$ (Tab. II). No significant difference $(P=0.16)$ was observed between the diagnosis of echography and the criteria of puberty (oestrus and/or progesterone); thus, the echographic diagnosis was concordant to the physiological status.

The time required for the examination and diagnosis depended, if it was a positive 


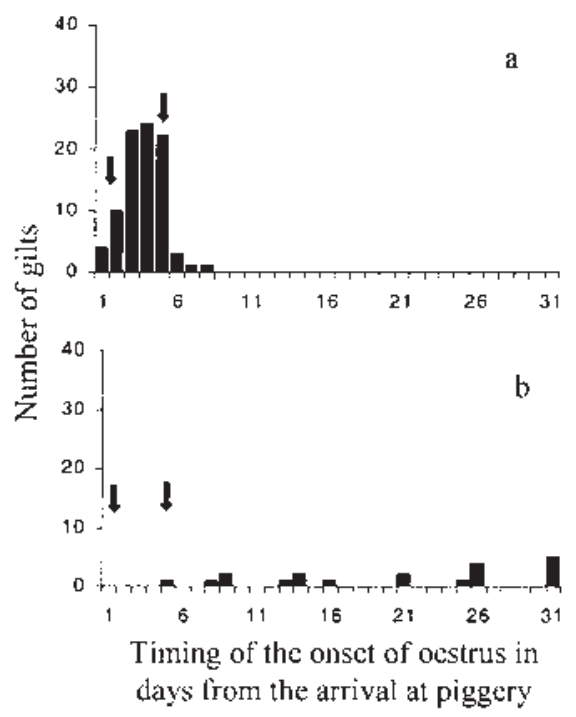

Figure 4. The occurrence of the onset of the first oestrus (experiment 3 ), (a) For gilts $(n=93)$ that were diagnosed + by Day 5 after arrival at the piggery (202 \pm 8 days of age). Arrows indicate the timing of the echographic diagnosis, (b) For gilts $(n=20)$ that were diagnosed twice -. Arrows indicate the timing of the echographic diagnosis.

or a negative diagnosis. Images of the pubertal uterus are easy to detect; but it took more time in cases of a negative diagnosis to be sure that a gilt was infantile or impubertal. It was approximately twice more time than for a pregnancy diagnosis that took around one minute. Only ultrasonography by the external route seems possible with using smaller size transducers because the place in the inguinal fold is narrow with gilts. Also, immobilisation of the gilt is necessary to obtain a better visualisation of the uterus, especially in infantile and impubertal females.

\section{DISCUSSION}

Our results show that the follow-up of the uterus by external ultrasound scanning during the peripubertal period demonstrated that qualitative and quantitative changes occur shortly before puberty. They also indicate that these changes may be used as an efficient tool for diagnosis of puberty. The overall accuracy rate of the diagnosis of puberty averaged $95.1 \%$ and $99.1 \%$ respectively for the experiments 2 and 3 .

These changes are related to the development of the uterus. During the first 70 days of life, uterine growth is slow [22] and the ovaries have no influence on uterine growth [23]. After this date, uterine growth begins and is associated with an increased oestrogen production. Development of the uterine glands, endometrium and myometrium is completed by 100 days of age [14, 24, 25]. The onset of puberty induced a marked increase in uterine horn weight and length. Probably as a result of stimulation by increased plasma oestrogen levels that occur just prior to oestrus [7].

The uterine changes around puberty can be detected by ultrasonography (experiment 1). A difference in the uterine echographic images was observed in pubertal gilts 3 days in mean before puberty. The mean "uterine area" increased during this period. These observations were in agreement with the fact that a number of social or environmental changes (transport, relocation and boar exposure) can precipitate the onset of puberty and in most of the gilts an oestrus was observed within the week after the transport stress (experiment 3: 79\% of the gilts were in oestrus within 7 days), $[7,10]$.

The echographic images of the uterus during the follicular phase have been described by Martinat-Botté et al. [16], Knox and Althouse [26] and Kauffold et al. [27]. Since the uterus has more tone during this period, the images change, becoming more contrasting. Slices of the uterus are clear and remain so until the end of the heat. These descriptions are similar to those given for the recorded images in pubertal gilts.

For infantile and impubertal gilts, the "uterine area" data did not increase during this follow-up (Experiment 1). The uterine 
growth seems slow. At slaughter, the mean uterine weight was the lowest in immature gilts compared to pubertal ones. Similar observations on the uterine weight of immature and pubertal gilts have been done by Kauffold et al. [27] and Prunier et al. [15] after examination of the genital tract at slaughter.

Kauffold et al. [27] have characterised the uterus by transcutaneous ultrasonography in gilts around puberty. For each gilt, the uterine horns were imaged in a cross-section and their diameters were measured. The mean sectional areas were calculated from the measured diameters. The mean sectional area was the lowest for impubertal animals compared to pubertal gilts with one or more sexual cycle. A strong positive correlation $(r=0.92)$ was found between the sectional area of the uterine horns and the uterine weight [27]. With a different parameter, "uterine area", we obtained similar results which were in agreement with those of Kauffold et al. [27].

From batch to batch, the onset of puberty is variable and is generally spread over several weeks $[6,7,28,29]$. For the breeders, such variability in the age of puberty is a problem for the introduction of the gilts in batches of farrowings. A diagnosis of puberty would facilitate entering into a breeding herd. The pattern of the development of "uterine area" is progressive and several quantitative measurements are required to be evidenced. The occurrence of well defined images of the uterus is sharp and always occurred a few days before puberty and remained after puberty, thus this parameter was retained for a puberty diagnosis. The difference of uterine images is also noted in gilts close to puberty - prepubertal females - and were considered as pubertal in the calculation mode of diagnosis accuracy.

The accuracy of the diagnosis changed according to the real physiological status of the gilts. The errors, less than $8 \%$, occurred only for the impubertal and prepubertal females (experiment 2). This technique allowed the detection of all pubertal females. Among those $8 \%$ had ovulated without oestrus being detected. The results from investigations carried out under field-conditions, have demonstrated high progesterone levels in pubertal gilts with no observed oestrous behaviour. For these studies, from 5 to 20 percent of the gilts did not show a standing reflex at the first oestrus. All these gilts ovulated, as judged by the progesterone levels [10, 30, 31]. Ultrasound scanning permitted to detect this population and the implementation was easier than the progesterone assay.

For experiment 3 , the examination done 5 days after the arrival at the piggery allowed to detect the gilts that had oestrus within the week. For the gilts with delayed oestrus ( $>11$ days after arrival), several examinations were necessary to know if puberty would occur.

\section{CONCLUSIONS}

The occurrence of puberty is a sudden event that is predictable by echography 3 days in mean before the onset of oestrus.

The difference of uterine images between pubertal and impubertal gilts can be used as an accurate diagnosis of puberty: more than $95 \%$ of accuracy with only one examination. No error of diagnosis was noted on pubertal gilts with or without oestrus.

This diagnosis will facilitate the entry of gilts into sow groups when sows are bred after weaning. Hence, it opens up a new possibility.

\section{ACKNOWLEDGEMENTS}

We thank J.P. Balusson (Aloka) who helped us to apply the equipment in echographic measurements, Alain Béguey, Odile Moulin (INRA-PRC) and Guy Renaud (UEICP-INRA) for their help in the preparation of the illustrations. 


\section{REFERENCES}

[1] Dagorn J, Boulot S, Le Cozler Y, Dourmad JY, Pellois H. Analyse des modalités de mise à la reproduction des cochettes dans les élevages français. Conséquences sur les carrières des truies. Journ Rech Porc en France 1997, 29: 115-122.

[2] Gordon I. Breeding pigs at younger ages. In: Gordon (Ed), CAB International, New York, 1997. p 60-76.

[3] Le Cozler Y, Dagorn J, Lindberg JE, Aumaître A, Dormad JY. Effect of age at first farrowing and herd management on long term productivity of sows. Livest Prod Sci 1998, 53: 135-142.

[4] Legault C, Gauthier MC, Caritez JC, Lagant H. Analyse expérimentale de l'incidence de l'âge à la première mise-bas et du type génétique sur la productivité de la truie. Ann Zootech 1996, 45: 63-73.

[5] Noguéra JL, Guéblez R. Incidence de l'âge à la première mise-bas et de la taille de la portée sur la carrière de la truie. Journ Rech Porc en France 1984, 16: 134-144.

[6] Després P, Martinat-Botté F, Lagant H, Terqui M, Legault C. Comparaison des performances de reproduction des truies appartenant à trois génotypes : Large-White (LW), Large-White « hyperprolifique » (LWh), Meishan (MS). Journ Rech Porc en France 1992, 24: 345-350.

[7] Evans ACO, O’Doherty JV. Endocrine changes and management factors affecting puberty in gilts. Livest Prod Sci 2001, 68: 1-12.

[8] Brooks PH, Cole DJA. The effect of the presence of a boar on the attainment of puberty in gilts. $\mathrm{J}$ Reprod Fertil 1970, 23: 435-440.

[9] Martinat-Botté F, Bariteau F, Badouard B, Terqui $\mathrm{M}$. Control of pig reproduction in a breeding programme. J Reprod Fertil Suppl 1985, 33: 211-228.

[10] Signoret JP, Martinat-Botté F, Bariteau F, Forgerit Y, Macar C, Moreau A, Terqui M. Control of oestrus gilts. I. Management-Induced $\mathrm{Pu}-$ berty. Anim Reprod Sci 1990, 22: 221-225.

[11] Camous S, Prunier A, Pelletier J. Plasma prolactin, LH, FSH, and estrogen excretion patterns in gilts during sexual development. J Anim Sci 1985, 60: 1308-1317.

[12] Elsaesser F, Parvizi N, Foxcroft G. Ovarian modulation of the oestradiol-induced LH surge in prepubertal and sexually mature gilts. J Reprod Fertil 1998, 113: 1-8.

[13] Elsaesser F, Parvizi N, Schmitz U. Inhibitory feedback action of oestradiol on tonic secretion of luteinizing hormone in pre- and postpubertal gilts. Anim Reprod Sci 1991, 25: 155-168.

[14] Erices J, Schnurrbusch U. Uterus development in swine from birth to age of eight months. Arch Exper Vet Med 1979, 33: 457-473.
[15] Prunier A, Bonneau M, Etienne M. Effect of age and live weight on the sexual development of gilts and boars fed two planes of nutrition. Reprod Nut Dev 1987, 27: 689-700.

[16] Martinat-Botté F, Renaud G, Madec F, Costiou P, Terqui M. Ultrasonography and reproduction in swine. Principles and practical applications. In: INRA Editions \& Hoechst Roussel Vet, Paris France. 2000.

[17] Signoret JP. Reproductive behaviour of pigs. J Reprod Fertil Suppl 1970, 11: 105-117.

[18] Terqui M, Guillouet P, Maurel M-C, MartinatBotté F. Relation between peri-oestrus progesterone levels and time of ovulation by echography in pigs and influence of the interval between ovulation and artificial insemination (AI) on litter size. Reprod Nut Dev 2000, 40: 393-404.

[19] Statistical Science S-P. S-PLUS Guide to Statistical and Mathematical Analysis, Version 3.4, Seattle: Stat. Sci. a division of MathSoft, Inc. 1996.

[20] SAS Institute Inc. SS. Guide for personal computers, Version 6.12, 1997.

[21] Littel RC, Henry PR, Ammerman CB. Statistical analysis of repeated measures data using S.A.S procedures. J Anim Sci 1998, 76: 1216-1231.

[22] Dyck GW, Swierstra EE. Growth of reproductive tract of gilt from birth to puberty. Can J Anim Sci 1983, 63: 81-87.

[23] Wu MC, Dziuk PJ. Ovarian influence on uterine growth in prepubertal gilts. J Anim Sci 1988, 66: 2893-2898.

[24] Bal HS, Getty R. Postnatal growth of swine uterus from birth to six months. Growth 1970 , 34: $15-30$

[25] Hadek R, Getty R. The changing morphology in uterus of growing pig. Amer J Vet Res 1959, 20: 573-577.

[26] Knox RV, Althouse GC. Visualizing the reproductive tract of the female pig using real-time ultrasonography. Swine Health Prod. 1999, 7: 207-215.

[27] Kauffold J, Rautenberg T, Richter A, Waehner M, Sobiraj A. Ultrasonographical characterization of porcine uterus: (I) Gilts. In: 16th International Pig Veterinary Society Congress Melbourne, Australia. 2000, p 385.

[28] Dyck GW. Factors influencing sexual maturation, puberty and reproductive efficiency in the gilt. Can J Anim Sci 1988, 68: 1-13.

[29] Eliasson L, Rydhmer S, Einarsson S, Andersson K. Relationship between puberty and production traits in the gilt. 1. Age at puberty. Anim Reprod Sci 1991, 25: 143-154.

[30] Christenson RK. Influence of confinement and season of the year on puberty and oestrous activity of gilts. J Anim Sci 1981, 52: 821-830.

[31] Eliasson L. A study on puberty and oestrus in gilts. J V Med 1989, 36: 46-54. 